\title{
レーザースペックル顕微鏡による単一細胞イメージング
}

\author{
平川靖之 \\ 久留米工業高等専門学校 電気電子工学科 ( ₹830-8555 福岡県久留米市小森野1-1-1)
}

\section{Imaging of Single Cell by Laser Speckle Microscopy}

\author{
Yasuyuki HIRAKAWA \\ Department of Electrical and Electronic Engineering, Kurume National College of Technology, \\ 1-1-1 Komorino, Kurume, Fukuoka 830-8555
}

(Received May 29, 2006)

\begin{abstract}
Laser speckle microscopy was developed to observe a single living cell without any troublesome labeling preparation. The system consists of an optical microscope, a laser source, and a video camera. The technique has an advantage that cellular conditions can be instantaneously determined by observing speckle fluctuations. In the experiments, living and fixed HeLa cells were compared on the basis of speckle fluctuation and frequency spectra. By applying this technique to cell observations, it is expected to estimate not only cellular activity but also real-time movements of intercellular materials including the cytoplasm without fluorescence observation.
\end{abstract}

Key Words: Laser speckle, Cell observation, Microscope, Cellular activity

1.はじめに

レーザースペックルは，ホログラムと同じ範疇に属す る光の干渉現象一つであり, ランダムな縞模様として観 察される。レーザースペックルは，観察する側の光学系 により， objective speckleと subjective speckleに大きく分け られるが1), 殆どの応用の場合, 光学系により結像してス ペックルを観察することから, subjective speckleを観察し ていることになる、レーザースペックルは現在, 産業的 には物理的な変異や表面のスムーズさ, 歪みを検出する 装置に応用されており1,2)，また，医療分野では，レー ザードップラー流速計と同様な血流モニタリングなどに 利用されている3-6). これらのレーザースペックルを利用 した計測法の利点は, 他のレーザー応用計測同様, 非接 触, 非侵襲, 非破壊という点にあるのはもちろん, CCD カメラにより画像を取得すれば，2次元イメージが容易に 得られるという点に大きな特徵がある.

医療分野及びバイオ研究の分野では, 細胞観察は非常 に基本的なものであり，細胞培養は欠くことのできない 作業である。しかしながら, 細胞培養は手間暇がかかる 上に, 専門的な知識が要求される. 培養している細胞 が，ある程度増えた時に新たな培養フラスコに移し替え る継代(けいだい)作業では, 位相差顕微鏡や微分干渉顕微 鏡による細胞状態の観察が必要不可欠である。この顕微 鏡による細胞状態の評価は, 細胞形状のみしか判断材料 がないため, オペレーターには十分な経験が必要とされ る.
著者は, 細胞内生体分子の一分子イメージングに関す る研究7,8)を行っていた際に, 偶然, 単一細胞上において もレーザースペックルが観察され，そのスペックルの縞 模様が細胞状態に応じて時間的な変化をすることを見い だした9)。これまで，ヒトの組織や植物細胞のレーザース ペックルによる観察は報告されているが6,10-12)，レーザー スペックルによる単一細胞観察は, 著者の知る限り, 著 者らによるものだけである。

実験では，まずレーザースペックル画像の処理法につ いて検討を行った後, 生細胞と固定化細胞(死細胞)におい て観察されるスペックル摇らぎについて比較を行った。 その結果，レーザースペックルの摇らぎが両者で全く異 なり, その周波数解析を行うと, 生細胞特有の周波数 ピークが存在することが明らかとなった。この周波数 ピークを処理することにより, 定量的な細胞活動評価実 現の可能性がある. 本レーザースペックル顕微鏡を利用 することで，煩雑な蛍光分子によるラベリング処理や特 別な技量無しで細胞状態を評価でき, 蛍光分子を利用す ることの難しい用途，例えば再生医療に利用する細胞の 評価等への応用が期待される.

\section{2. 実験装置}

実験装置の概略図をFig. 1に示す．顕微鏡(Zeiss，Axioplan) のステージ上に, 試料の入った $35 \mathrm{~mm} ゙$ イッシュをセット し，ほぼ水平横方向 (入射角80～85度) からレーザーを照 射する。この入射角は, 試料と対物レンズ間の空間など 


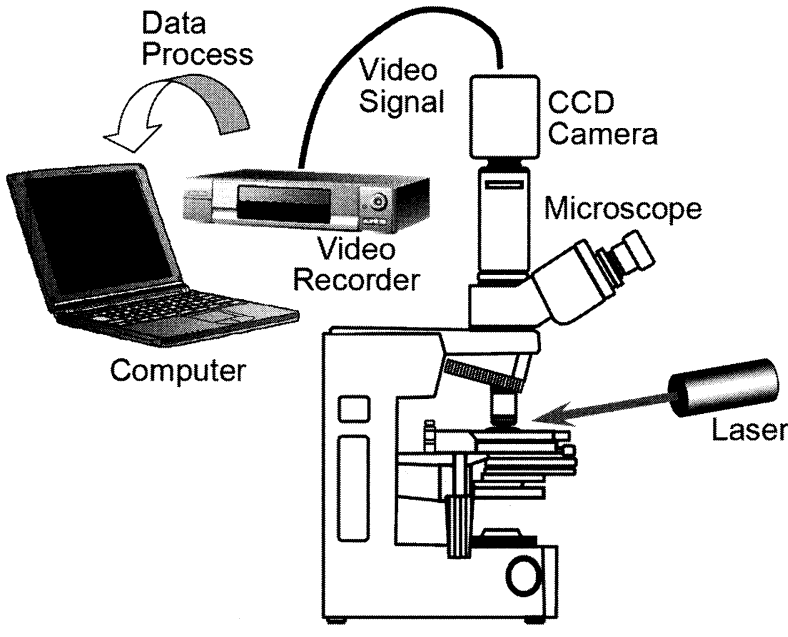

Fig. 1 Experimental setup.

の物理的な条件によって決まり，市販のレーザー顕微鏡 のように，対物レンズを通して照射しても支障はない. レーザーには, 半導体レーザー (シグマ光機, LDH2-6353, $635 \mathrm{~nm}, 3 \mathrm{~mW}$ ), 及び半導体レーザー励起YAGレー ザー(Crystalaser, Model BCL-005-M， 473 nm，5 mW)の2 種類を使用した。また，偏光状態による影響を避ける場 合には，光ファイバー(Thorlabs，SM500)を通してランダ ム偏光とし，試料近傍までファイバーで導いて照射し た。観察したレーザースペックル像はCCDカメラ (SONY，SSC-DC430)を使って，デジタルビデオレコー ダー (SONY，DSR-30)に動画として記録した。 その後, コンピューターに取り込んだ後に静止画に落とし，画像 解析を行った。

観察試料には， $35 \mathrm{mmディッシュ内のカバーガラス上で}$ フェノールレッド入り培地 (Sigma-Aldrich, D6046)を使っ て培養したHeLa細胞を用いた。細胞を観察する際には, 明瞭な像を得るために，フェノールレッド抜き培地 (Sigma-Aldrich，D5921）に交換した．細胞培地の温度を変 化させながら観察を行う場合には，細胞が乗ったカバー ガラスを直接電気ヒーター上のシリコンゴムに置いて実 験を行った．温度はセンサーヘッド部が独立した温度計 (Custom，CT-110)を使って直接培地にヘッドを挿入して 測定した。固定化細胞 (死細胞) は，ホルムアルデヒド (Nacalai tesque，371-52)に10分間浸すことで用意し，生細 胞と同じ培地を用いて観察を行った.

本レーザースペックル顕微鏡の主な特徽として, 以下 の5点を挙げることができる。

(1)装置が単純である,

(2)微弱なレーザー光で照明可能,

(3) 観察対象は散乱光の干渉現象であるので，高感度な検 出器が不要,

(4) 観察光は照明光であるので，適切に照明波長を選択す れば，蛍光同時観察も可能，

(5)試料である細胞には一切前処理が必要ない.

（1）については，照明光源がレーザーであれば良いので, 全ての市販の生物顕微鏡をスペックル顕微鏡として構成 することが可能である。また，レーザーも連続動作
(CW)，パルス動作，波長，出力等のパラメータに殆ど制 限がない，観察光に科せられる制限としては，空間的コ ヒーレンスがある程度あり, 試料に光損傷を与えないと いう条件だけある。このため，(2)に示すように， $\mathrm{mW}$ オーダーの微弱なレーザー(例えば半導体レーザーなど)で も問題なく光源として利用できる。観察する対象は散乱 されたレーザー光同士の干渉光であるため，蛍光等に比 べると数桁強度は高い。そのため，(3)に示したように高 感度な検出器は不要で，一般に市販されている通常感度 のCCDカメラで十分である．また，観察する光は照明光 であるため, 照明光(励起光)とは通常異なる波長で発生す る蛍光も，検出器さえ高感度なものを用意すれば，同時 観察が可能である。そして, 最も重要な特徵が, (5)の細 胞に一切の前処理が不要である点である。これは, 殆ど の場合，蛍光分子の結合や遺伝子的な導入が必要になる 蛍光観察に対する大きな利点である．同じく前処理の不 要なレーザー顕微鏡として, 多光子顕微鏡が挙げられる が，フェムト秒レーザーが必要なためどうしても装置が 高額となる上，フェムト秒レーザーの高尖頭出力による 光損傷が必ずしも無視できるわけではない13)ため，慎重 に光強度を調整する必要がある。もちろん，蛍光観察や 多光子顕微鏡による高感度観察では到底敵わないが，前 処理が一切不要で微弱な光源で容易に細胞観察が行える 点は，レーザースペックル顕微鏡が従来のレーザー顕微 鏡に対する優位点になりうると考えられる。

\section{3. 実験結果}

レーザースペックル顕微鏡で得られるデータはビデオ イメージであるので，スペックルの摇らぎを定量的に評価 する方法について検討を行った. speckle contrast法4,14,15), average difference法 ${ }^{16)}$ はレーザースペックルを解析する際 によく使われる方法である。この二つの手法と，単純な フーリエ変換を用いた解析法で, 同じスペックル動画 データの解析を行ったところ，フーリ工変換を利用する 解析法が, 肉眼で得られる印象に最も近い結果が得られ たこと，計算時間も高速フーリエ変換を利用することで 短縮できることから，フーリエ変換処理を本研究では採 用することとした. Fig. 2に，本研究で採用した動画像処 理法の流れ図を示す.コンピューターに動画を取り込ん だ後に，フレーム毎に静止画として保存する。コン ピュータのメモリや処理時間の制限から，元画像の解像 度を以下の要領で下げた。すなわち，保存した静止画を 適切な大きさの画素単位で区切り，その画素内で画像輝 度の平均值をとることで解像度の低減を行った。低解像 度化した後，注目する画素の輝度の時間変化を取り出 し，高速フーリエ変換することで周波数スペクトルを得 る．更に，周波数軸に渡って積分することで，その注目 した画素の輝度変化のパワーに相当するものを算出し た。なお，これらの処理は，市販アプリケーションによ るブラックボックス的な処理を避け，輝度情報や解像度 の保存を図るため，全て自作のプログラムを用いて行っ た。 


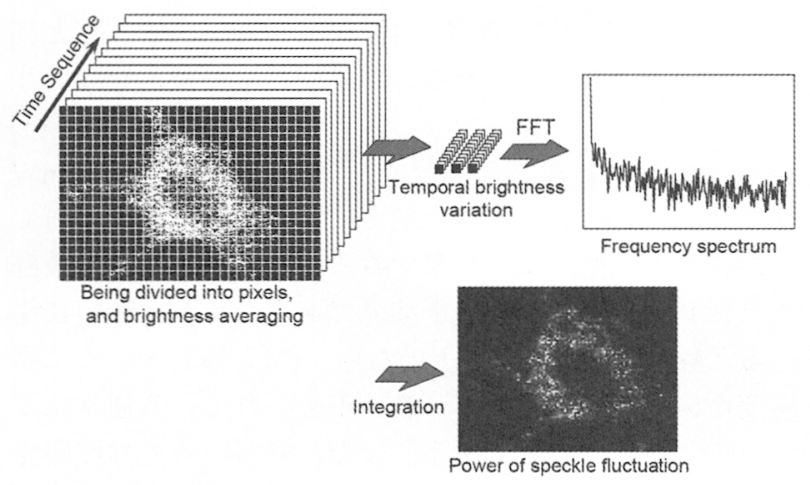

Fig. 2 Procedure for derivation of speckle fluctuation power.

まずはじめに，観察される細胞上のレーザースペックル が，照明波長・レーザー光入射角度により大きな影響を 受けないことを確認した。しかし，レーザー光に直線偏 光を用いる場合には，その偏向方向が観察されるスペッ クルに影響を及ぼすことが実験的に明らかになった。そ こで，以下の実験では，照明光導入の簡便化も図るため に，光ファイバーにレーザー光を入射してランダム偏光 とし，試料近傍までレーザー光を導き照明することとし た。

Fig. 3には，生細胞と固定化細胞のスペックル摇らぎを 比較した結果を示す. Fig. 3の (a) と (b) は, 生細胞と固定 化細胞それぞれのハロゲンランプ照明による明視野像で ある。レーザースペックルの静止画像は (c)と (d)に示す。 (e) と (f) は，上述の手順により導出したレーザースペック
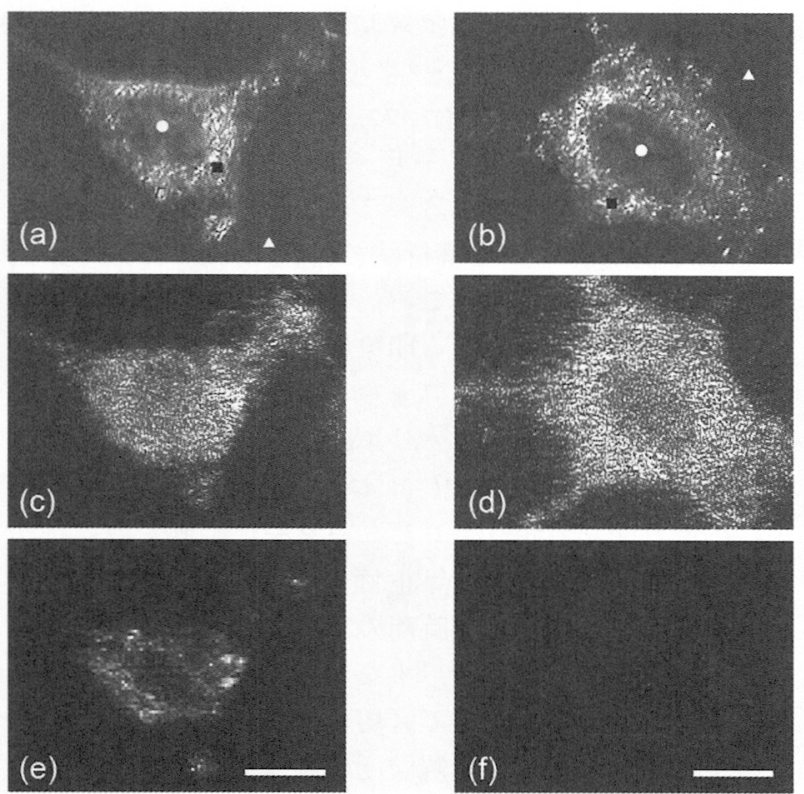

Living Cell

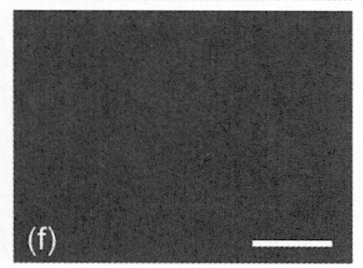

Fixed Cell

Fig. 3 Observed laser speckle on a living cell (left column) and fixed cell (right column). (a), (b) bright field images, (c), (d) speckle still images, and (e), (f) speckle fluctuation power. The scale bars in (e) and (f) are $10 \mu \mathrm{m}$. In (a) and (b), sampling points are also indicated for calculating fluctuation spectra for active (bright) part (black square), nucleus part (white circle), and medium part (white triangle) in Fig. 5.

ル摇らぎのパワーを示している。この結果は具体的には 以下の手順により導出した。まず，17.07秒間のビデオ画 像を512枚の静止画に変換する。本来の解像度は, $720 \times$ 480ピクセルであるが，これを一つの細胞だけの画像とな

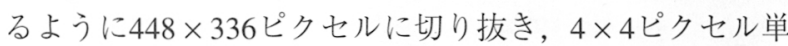
位で平均化して切り分けて, $112 \times 84$ ピクセルに変換し た。この後，同じ行・列のピクセルの輝度の時間変化を 取り出し, 高速フーリ工変換を使って周波数領域に変換 し，周波数に関して積分することで，相対的なレーザー スペックルの摇らぎパワーを算出した. 異なる条件で撮 影したスペックル像は, 明るさやコントラスト等を補正 するために, 輝度から直流成分を取り除き, 更に細胞の 存在しない細胞培地部分を基準にして, 細胞部分のス ペックルを評価した。なお，使用したCCDカメラのフ レームレートは30 frames/sなので，Nyquist周波数より，こ の解析により評価できる周波数域は $15 \mathrm{~Hz} ゙$ 上限である。 この操作により得られた典型的な結果が先のFig. 3 (e) と 5 (f)である。この図では, 白い点ほどスペックル摇らぎ が大きく，黒い点ほど動かないことを示している，平均 的なレーザースペックル摇らぎのパワーは, 生細胞の方 が固定化細胞よりも明らかに高いことが分かる。この差 異は動画を見れば一目瞭然であるが，このように静止画 としても定量化できることが示された。この生細胞と固 定化細胞におけるスペックル摇らぎの差がどのような周 波数成分に主に依るものなのかを調べてみたところ, Fig. 4に示すような結果が得られた。すなわち, 生細胞ではス ペクトル領域全体に渡って強度が大きく，固定化細胞と の差異がはっきりしているばかりではなく，*で図中に 示した数 $\mathrm{Hz} の$ 低周波域に生細胞特有のピークが存在する ことが明らかとなった。これをより分かりやすく示した のが，Fig. 5のカラーで示した周波数スペクトルの時間変 化のグラフである。これらの6つのグラフは, Fig. 3(a), (b) 中に示した回 (Fig. 3 (e)，（f)で明るく表示される摇ら ぎの大きい部分), $\bigcirc$ (核の部分)， $\Delta$ (培地の部分)に対す るものをそれぞれ示しており，約30秒間の動画デー夕を

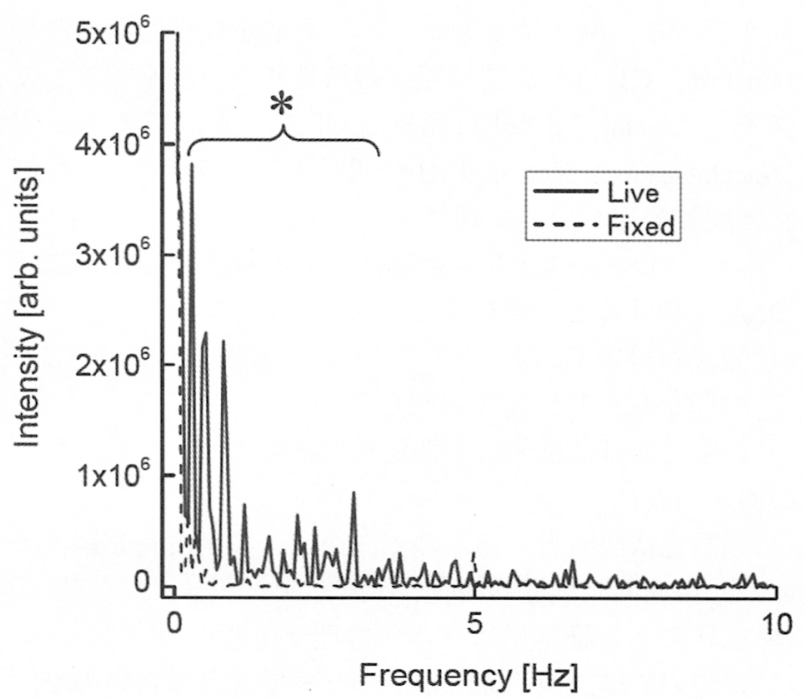

Fig. 4 Frequency spectra of speckle fluctuation for active (bright) points in living/fixed cell. 

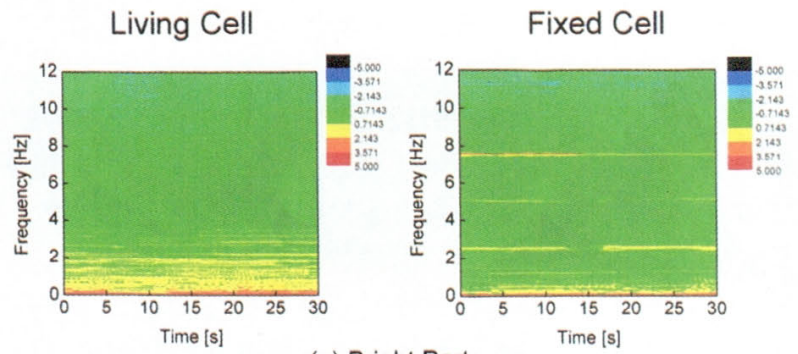

(a) Bright Part
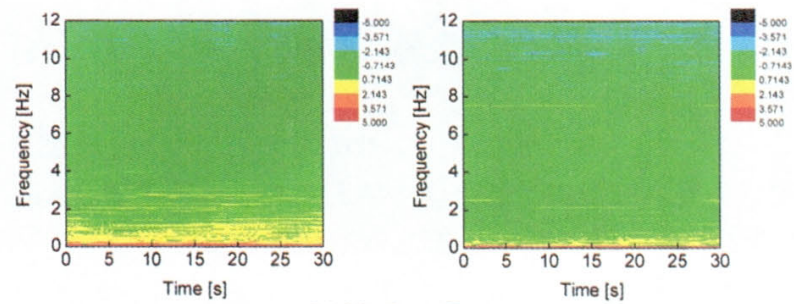

(b) Nucleus Part
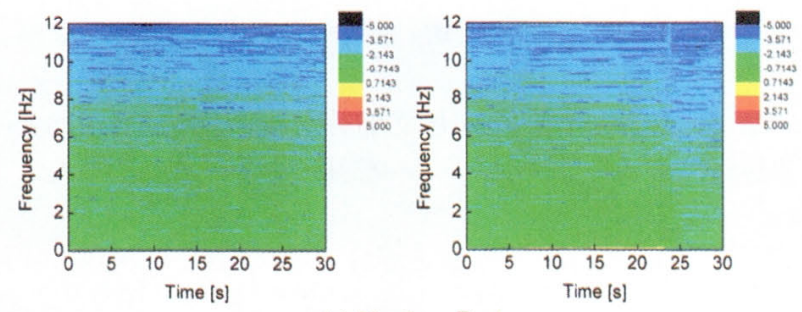

(c) Medium Part

Fig. 5 Temporal variation of speckle fluctuation spectra for three-different points, bright (active), nucleus, and medium points.

利用し解析を行ったものである，グラフでは，赤い部分 ほどスペクトル強度が高く, 青に移るにつれて強度が下 がっていることを示す．細胞の存在しない培地部分のス ペクトル時間変化 (Fig. 5 (c)) が, 生細胞. 固定化細胞, どちらの場合も殆ど差がないのに対し, 生細胞のスペッ クル摇らぎの大きな部分 (Fig. 5 (a) 左) 及び核部分 (Fig. 5 (b)左)のスペクトル時間変化はともに, 黄色で示される比 較的強度の大きな部分が多いことが分かる．固定化細胞 の場合は，解析に使用したデー夕に観察時のノイズが多 少乗っているが，生細胞に比較すると黄色の部分が明ら かに少なく,この図からも生細胞のスペックル摇らぎが 大きいことが確認できる，生細胞の核部分も，スペック 儿摇らぎの大きな箇所とほぼ同じような傾向を示すが, そこと比較すると若干強度が低い様子が分かる。

細胞活動とレーザースペックル摇らぎの相関をより明 確にするために，レーザースペックル摇らぎのパワーに ついて更に詳しく検討を行った. Fig. 6は生細胞と固定化 細胞のレーザースペックル摇らぎの培地温度依存性を調 ベた結果である。グラフにプロットしたデータは生細胞 は10個の, 固定化細胞は2個の細胞の平均値である，固定 化細胞のサンプル数が少ない理由は，固定化細胞におけ るレーザースペックルは生細胞に比較して非常に安定し ており，デー夕の摇らぎが少なかったためである. Fig. 6 に示すように，固定化細胞に関しては，レーザースペッ クル摇らざの温度との相関性は殆ど見られないのに対 し, 生細胞では, 温度とともに単調に増加する傾向が見

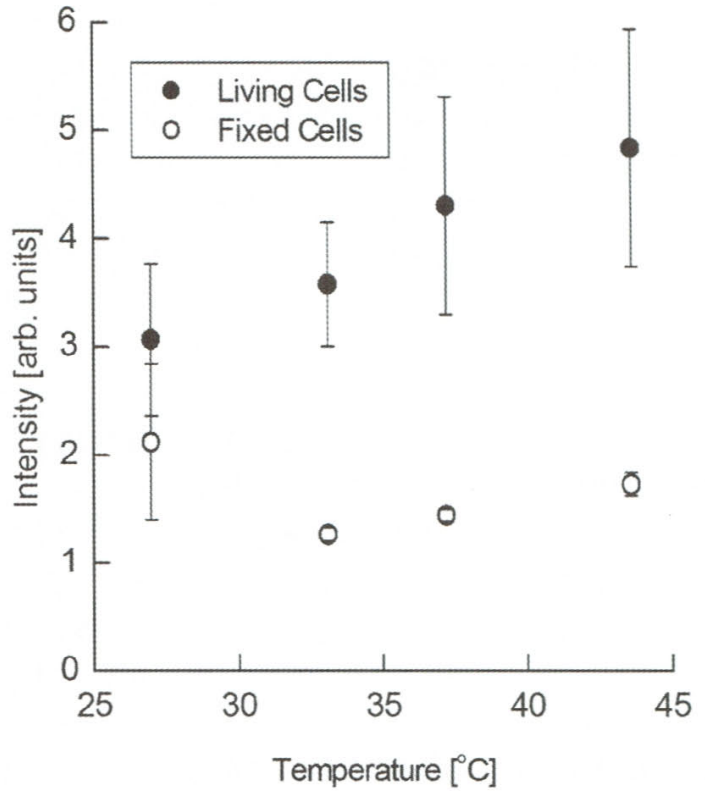

Fig. 6 Temperature dependences of speckle fluctuation for living cells and fixed cells.

られる. 使用した温度制御装置が冷却機能を有しない上 に, $45^{\circ} \mathrm{C}$ 以上では, カバーガラスから細胞が剥がれてし まったため，25〜 $45^{\circ} \mathrm{C} の$ 範囲外におけるレーザースペッ クル像を得ることはできなかったが， $45^{\circ} \mathrm{C}$ 以上における 生細胞のレーザースペックルは, 目視では明らかに $45^{\circ} \mathrm{C}$ 以下のそれよりも活動度は低いことが確認できた。この

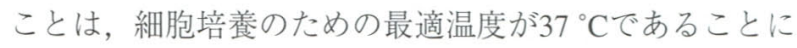
符合しており，生細胞におけるレーザースペックル摇ら ぎの度合いは細胞活動と密接に関倸していることを強く 示唆している10,11).

\section{4. 考 察}

Fig. 3の結果からも分かるように, 生細胞のレーザース ペックル摇らぎは強く, 固定化細胞のそれは殁どない。 しかしながら, どちらの状態でも細胞構造は明視野像で もレーザースペックル静止画でも像の明暗として観察で きる。例えば，細胞核でのスペックルは，Fig. 3 (c) と (d) のように常にその周辺部よりも暗く観察される。一方, Fig. 6から分かるように，培地温度上昇による細胞活動の 活発化に伴って,レーザースペックル摇らぎが激しく なっている。これらのことを総合的に勘案すると, 細胞 上で観察されるスペックルは，2つの異なるタイプから構 成されているという可能性が考えられる。一つのスペッ クルは活動的な型で，もう一つは動かない型のスペック ルである ${ }^{4)}$ 。この動かないスペックルは, 中間径フィラメ ントなどの細胞構造を反映して決定されると考えられ， そのため固定化細胞でもスペックルが観察されていると 考えられる。一方, 活動的なスペックルは, 細胞膜の動 き, 並びに細胞内の小器官やATP (adenosine triphosphate, ア デノシン三リン酸) 産生活動に関係する生体分子の動きを 反映している12) と考六られる。これまで，植物の葉緑素 の動きに応じたスペックル摇らぎの観察が報告されてい 
る10)ことから, 細胞内小器官や生体分子がレーザース ペックルに影響を及ほしていると考えるのは自然であ る. 今回の実験では, 装置の空間的な制限からレーザー 光入射角度が 80 度程度となったが，レーザースペックル について，入射角度依存性について調べたところ，入射 角の大きな影響は観察されないことが分かった。更に， 細胞膜の屈折率 (1.37程度) と培地の屈折率 (殆ど水で構成 されると考えると 1.33 程度)を考慮すると, 細胞膜での全 反射は起こらないため, 観察されているスペックルは, 大きなレーザー入射角による細胞膜上での反射により， 細胞膜の情報を含んでいることは当然考えられるが，そ ればかりではなく, 細胞内部に光が入り込み, 内部構造 や内部物質により散乱され生じたスペックルが観察され ていると推測される。細胞核部分のスペックル摇らぎが 少なく評価される原因については, 細胞核が存在する部 分は, 細胞の他の部分に比べて空隙が少なく, 細胞質等 の物質移動が少なくなっていることを示している可能性 も考えられる. また，Fig. 4の周波数スペクトルからは， 低周波域に特徽的な周波数ピークのあることが分かる が，これは細胞質などの流体の比較的ゆったりした動き に依る可能性も示唆しているとも考えられる。これらの 現象を確認するには，ある特定分子に蛍光夕グを結合さ せて観察する蛍光顕微観察を同時に行って検討する必要 があり，これからの課題である。

現在の装置的な課題として, 使用しているCCDカメラの フレームレートが30 frames/sであるため, 解析可能な周波 数が $15 \mathrm{~Hz}$ 上限であることが挙げられる，そのため，高 速度カメラを用いた，より高い周波数領域の解析を検討 している. 細胞内生体分子の多くは, 細胞内で激しいブ ラウン運動をしていると考えられるため, 高速度カメラ による高周波領域の解析により, 前処理の何ら施されて いない生(なま)の細胞の情報を, 蛍光観察に依ることなし に明らかにできる可能性がある。また，ある特定の分子 の吸収線に適した波長のレーザー光を照射光として用い ることで, 細胞内生体分子を追跡する可能性も考えられ る.
5. まとめ

レーザースペックル顕微鏡によりヒトの単一細胞の観 察を行った。生細胞と固定化細胞を比較すると，生細胞 でのレーザースペックル摇らぎは明らかに固定化細胞よ りも活発であり，摇らぎの周波数スペクトル解析を行う と，低周波域に生細胞特有のピークが存在することが分 かった。また，レーザースペックル摇らぎの温度依存性 を計測したところ，生細胞のレーザースペックル摇らぎ は，温度に比例して活発になり，細胞活動を反映してい ることを確認することができた。本研究により，レー ザースペックル顕微鏡が，ラベリングなどの前処理が不 要であり，細胞に損傷を全く与えずに細胞状態を定量的 に評価できるユニークな細胞観察法となる可能性を示す ことができた。

\section{謝 辞}

この研究は2004-2005年度文部科学省科学研究費補助金 基盤研究 (C) 16590028による一部補助を受けて行われた.

\section{参考文献}

1) R. Jones and C. Wykes: Holographic and Speckle Interferometry (Cambridge University Press, Cambridge, 1989) Chap. 7.

2) 岡本 卓，朝倉 利光：計測と制御 32（1993） 667.

3) Y. Aizu and T. Asakura: Opt. Laser Tech. 23 (1991) 205.

4) J. Briers: Opt. Eng. 32 (1993) 277.

5) B. Choi, N. Kang, and J. Nelson: Microvasc. Res. 68 (2004) 143.

6) J.S. Paul, A.R. Luft, E. Yew, and F.-S. Sheu: NeuroImage 29 (2006) 38.

7) Y. Hirakawa, M. Suzuto, H. Ohnishi, T. Shingaki, E. M. Eyring, M. Tokunaga, and T. Masujima: Analyst 128 (2003) 676.

8) M. Suzuto, Y. Hirakawa, H. Ohnishi, S. Tachino, T. Shingaki, E. M. Eyring, and T. Masujima: Anal. Sci. 19 (2003) 43.

9) Y. Hirakawa, T. Hasegawa, and T. Masujima: Jpn. J. Appl. Phys. 44 (2005) L85.

10) J. Briers: Optic. Commun. 13 (1975) 324.

11) A. Oulamara, G. Tribillon, and J. Duvernoy: J. Mod. Optic. 36 (1989) 165.

12) P. Yu, L. Peng, M. Mustata, J. Turek, M. Melloch, and D. Nolte: Opt. Lett. 29 (2004) 68.

13) Y. Hirakawa: in Recent Developments in Lasers and their Applications ed. N. J. Vasa (Research Signpost, Kerala, 2006) Chap. 7.

14) J. Briers, and S. Webster: Optic. Commun. 116 (1995) 36.

15) A. Fercher, and J. Briers: Optic. Commun. 37 (1981) 326.

16) H. Fujii, K. Nohira, Y. Yamamoto, H. Ikawa, and T. Ohura: Appl. Opt. 26 (1987) 5321. 